\title{
Peran Zinkum Terhadap Pertumbuhan Anak
}

\author{
Leon Agustian, Tiangsa Sembiring, Ani Ariani \\ Departemen Ilmu Kesehatan Anak Fakultas Kedokteran Universitas Sumatera Utara / RSUP H. Adam \\ Malik Medan
}

\begin{abstract}
Zinkum merupakan zat yang esensial dan berperan dalam reaksi yang luas dalam metabolisme tubuh, terdapat di hampir semua sel tubuh terutama tulang dan otot. Zinkum banyak dijumpai pada daging, susu, dan beberapa makanan laut. Angka kecukupan $\mathrm{Zn}$ yang dianjurkan 3-5 mg/hari (bayi), 8 -10 mg/ hari (1-9 tahun), dan $15 \mathrm{mg} /$ hari ( $\geq 10$ tahun). Dalam proses pertumbuhan, $\mathrm{Zn}$ berperan dalam sintesis protein yang dibutuhkan untuk pembentukan jaringan baru, pertumbuhan, dan perkembangan tulang. Anak mempunyai risiko yang lebih tinggi untuk mengalami defisiensi. Pemberian suplementasi $\mathrm{Zn}$ pada bayi dan anak memberikan efek yang positif terhadap pertumbuhan. (Sari Pediatri 2009;11(4):244-9).
\end{abstract}

Kata kunci: zinkum, sintesis protein, pertumbuhan

$\longrightarrow$ inkum (Zn) merupakan zat yang esensial untuk kehidupan, telah diketahui sejak lebih dari seratus tahun yang lalu. Peran penting zat ini untuk pertumbuhan normal dan kesehatan manusia telah diteliti sejak tahun 1930an oleh Mc Lance dan Widdowson ${ }^{1}$ yang melakukan penelitian tentang metabolisme Zn. Pada akhir tahun 1960-an dan awal tahun 1970-an diperoleh laporan pertama tentang kegagalan pertumbuhan pada remaja di delta sungai Nil di Mesir yang dapat diperbaiki dengan pemberian suplementasi $\mathrm{Zn} .^{2-3}$ Pengertian mendalam selama 20 tahun terakhir menghasilkan pemahaman lebih baik tentang peran biokimia di dalam tubuh dan gejala klinik yang timbul akibat defisiensi $\mathrm{Zn} .{ }^{1}$

\footnotetext{
Alamat korespondensi

Dr. Leon Agustian. Bagian Ilmu Kesehatan Anak. FK-USU/RS H Adam Malik, Medan. Jl. Bunga Lau no. 17, Medan 20136. Telepon: 061-836 1721. Fax. 061-836 1721.
}

Proses tumbuh-kembang merupakan proses yang berkesinambungan mulai dari konsepsi sampai usia 18 tahun, yang mengikuti pola tertentu yang khas untuk setiap anak. ${ }^{4}$ Faktor gizi merupakan salah satu faktor yang menentukan dan memegang peran penting dalam proses tumbuh kembang anak, karena kebutuhan anak berbeda dengan orang dewasa. ${ }^{4,5}$ Anak membutuhkan $\mathrm{Zn}$ lebih banyak untuk pertumbuhan dan perkembangan secara normal, melawan infeksi, dan penyembuhan luka. Anak yang dalam proses tumbuh kembang dan anak yang mengalami kekurangan gizi mempunyai risiko yang lebih tinggi untuk mengalami defisiensi. ${ }^{6} \mathrm{Di}$ negara berkembang, defisiensi $\mathrm{Zn}$ banyak dijumpai pada bayi dan anak yang menyebabkan retardasi pertumbuhan, bersamaan dengan tingginya angka kejadian penyakit infeksi yang berat seperti diare, pneumonia, dan malaria. ${ }^{7-9} \mathrm{Di}$ Indonesia, defisiensi Zn merupakan salah satu masalah gizi pada balita disamping kurang energi protein serta kekurangan zat gizi yang lain seperti vitamin A, zat besi, dan 
iodium. ${ }^{10}$ Sampai saat ini, Indonesia belum mempunyai data yang berskala luas mengenai defisiensi Zn. Studi berskala kecil (1997-1999) di Jawa Barat, Jawa Tengah, dan Lombok memperlihatkan prevalensi defisiensi $\mathrm{Zn}$ pada bayi berkisar 6\%-30\%. ${ }^{11}$

\section{Sumber Zinkum}

Zinkum merupakan mineral mikro (trace element) yang paling penting setelah besi. ${ }^{12}$ Mineral mikro adalah mineral yang dibutuhkan tubuh dalam jumlah 100 mg atau kurang setiap harinya. Zinkum pada makanan banyak dijumpai pada daging, susu, dan beberapa makanan laut, yang berasal dari sumber hewani diserap lebih baik daripada sumber nabati yang sering diikat oleh fitat. Zinkum dalam makanan berkorelasi dengan besi dan tembaga. Makanan dengan kadar besi tinggi akan menurunkan penyerapan $\mathrm{Zn}$, namun dapat menurunkan penyerapan tembaga. ${ }^{2}$

Tubuh membutuhkan Zn 4-6 mg/hari, ${ }^{6}$ berdasarkan AKG (angka kecukupan gizi) yaitu untuk bayi 5 $\mathrm{mg} /$ hari, usia 1-10 tahun $10 \mathrm{mg} /$ hari, dan untuk anak di atas usia 10 tahun $15 \mathrm{mg} /$ hari., ${ }^{5}$ Di Indonesia, angka kecukupan $\mathrm{Zn}$ yang ditetapkan berdasarkan Widya Karya Pangan dan Gizi tahun 1998 adalah untuk bayi 3-5 mg/hari, usia 1-9 tahun $8-10 \mathrm{mg} /$ hari, dan usia 10 tahun atau lebih membutuhkan 15 mg/hari. ${ }^{1}$

\section{Penyerapan dan metabolisme zinkum}

Penyerapan dan metabolisme $\mathrm{Zn}$ menyerupai penyerapan dan metabolisme besi. ${ }^{1}$ Penyerapan terjadi di duodenum, bila kadar di dalam darah rendah maka Zn lebih banyak diserap. Namun apabila asupan Zn tinggi dan kadar yang diserap tinggi, maka di dalam sel mukosa dinding usus halus terbentuk protein metalotionein yang akan mengikat $\mathrm{Zn}$ dan masuk ke aliran darah. ${ }^{2}$ Zinkum yang diserap dibawa oleh albumin dan transferin ke hati. ${ }^{14}$ Kelebihan $\mathrm{Zn}$ akan disimpan di hati dalam bentuk metalotionein, sisanya disimpan di pankreas dan jaringan tubuh lainnya seperti kulit, rambut, kuku, tulang, retina, dan organ reproduksi laki-laki. ${ }^{12}$ Di dalam pankreas, Zn digunakan untuk membuat enzim pencernaan, yang pada waktu makan akan disekresikan ke dalam saluran cerna. Sirkulasi di dalam tubuh dari pankreas ke saluran cerna dan kembali ke pankreas disebut sirkulasi entero-pankreatik. ${ }^{1}$
Metalotionein diduga berperan dalam mengatur kadar $\mathrm{Zn}$ di dalam cairan intraselular. Distribusi antara cairan ekstraselular, jaringan, dan organ dipengaruhi oleh keseimbangan hormon dan keadaan stres. Hati mempunyai peran penting dalam redistribusi $\mathrm{Zn}^{1}$ dan didistribusikan ke semua jaringan tubuh, namun dalam kadar yang berbeda. ${ }^{15}$ Tubuh manusia mengandung 2-2,5 gram $\mathrm{Zn}$ yang tersebar di hampir semua sel seperti hati, pankreas, ginjal, otot, dan tulang. Jaringan yang banyak mengandung $\mathrm{Zn}$ adalah mata, kelenjar prostat, spermatozoa, kulit, rambut, dan kuku. ${ }^{12,13}$ Porsi yang terbesar terdapat dalam tulang dan otot sekitar $65 \% .^{12}$

Konsentrasi Zn serum yang normal sekitar 80-140 ug/dl, ekskresi terutama melalui cairan pankreas, intestinal dan keluar bersama feses. Pengeluaran melalui saluran cerna lebih kurang 50\% dari ekskresi Zn. ${ }^{1}$ Pengeluaran melalui urin sekitar 500 ug/hari, ${ }^{15}$ sedangkan ekskresi melalui jaringan tubuh lain terjadi dalam kulit, sel dinding usus, cairan haid, dan sperma. ${ }^{1}$

\section{Peran zinkum}

Zinkum memegang peran esensial dalam banyak fungsi tubuh, ${ }^{1}$

1. Bagian integral dari enzim dan sebagai kofaktor enzim. Zink berperan sebagai bagian dari 70 sampai 200 enzim, ${ }^{13}$ yang sebagian besar termasuk kelompok metalloenzymes. Sebagai contoh, ${ }^{15}$

- Karboksi-anhidrase esensial membawa karbondioksid ke paru, sebagaimana hemoglobin yang berperan membawa oksigen.

- Laktat dehidrogenase dibutuhkan dalam perubahan piruvat dan asam laktat pada proses glikolisis.

- Alkali fosfatase dibutuhkan dalam metabolisme tulang, kadar tinggi dijumpai di dalam leukosit.

- Karboksi peptidase dan amino peptidase berperan dalam proses pemindahan karboksil terminal dan kelompok asam amino dalam metabolisme protein.

- Alkohol dehidrogenase bekerja di hati. Oksidasi tidak hanya etanol namun juga alkohol primer dan sekunder yang lain seperti metanol dan etilen glikol yang berfungsi dalam mekanisme detoksifikasi mayor. 
2. Berperan sebagai kofaktor enzim DNA polimerase dan RNA polimerase, yang diperlukan dalam sintesis DNA, RNA, dan protein. Peran $\mathrm{Zn}$ dalam pertumbuhan jaringan terutama berhubungan dengan fungsi dalam pengaturan sintesis protein. Metaloenzim DNA dan RNA polimerase dan deoksitimidin kinase sangat penting dalam sintesis asam nukleat, yang dibutuhkan untuk penyimpanan timin pada DNA. ${ }^{16}$ Katabolisme RNA diatur oleh $\mathrm{Zn}$ dengan mempengaruhi kerja ribonuklease. Enzim deoksinukleotil-transferase, nukleosid-fosforilase, dan reverse-transkriptase juga membutuhkan Zn untuk kerja. Zinkum juga dibutuhkan dalam proses transkripsi DNA.,

3. Sebagai bagian dari enzim kolagenase, zinkum berperan dalam sintesis dan degradasi kolagen. Dengan demikian, Zn dibutuhkan dalam pembentukan kulit, metabolisme jaringan ikat, dan penyembuhan luka. ${ }^{1}$

4. Berperan dalam produksi hormon pertumbuhan (Growth Hormon/GH). Zinkum dibutuhkan untuk mengaktifkan dan memulai sintesis hormon pertumbuhan. Pada defisiensi Zn akan terjadi gangguan pada reseptor $\mathrm{GH}$, produksi $\mathrm{GH}$ yang resisten, berkurangnya sintesis Liver Insulin Growth Factor (IGF) $-I$ dan protein yang membawanyal binding protein (BP) yaitu IGFBP-3. Peran $\mathrm{Zn}$ dalam produksi hormon pertumbuhan akan menyebabkan terjadinya perubahan pada $G H$ axis. ${ }^{12,17}$

5. Memobilisasi vitamin A dari hati untuk menjaga konsentrasi yang normal dalam sirkulasi darah. Zinkum penting untuk sintesis retinol-binding protein yang mengangkut vitamin A dalam darah. $^{3,18}$

6. Berperan dalam fungsi imunitas, zinkum diperlukan untuk fungsi sel $T$ dan pembentukan antibodi oleh sel B. Defisiensi $\mathrm{Zn}$ menyebabkan atropi timus, berkurangnya produksi limfokin,hormon yang diproduksi oleh timus, natural killer cell, aktifitas limfosit, dan reaksi hipersentitifitas tipe lambat. ${ }^{12,19}$ Hubungan antara $\mathrm{Zn}$ dengan imunitas tubuh ini telah banyak diketahui. Shankar dan Prasad $^{20}$ menyatakan bahwa Zinkum berperan dalam aktifasi limfosit $T$, produksi Th-1, dan fungsi limfosit B. Fraker $\mathrm{dkk}^{21}$ di Amerika Serikat, mendapatkan hasil bahwa terdapat rangkaian yang dinamis antara status imunitas dengan status $\mathrm{Zn}$. Pada defisiensi $\mathrm{Zn}$ yang berat seperti pada penyakit
Akrodermatitis enteropatika terjadi gangguan pada imunitas seluler dan memudahkan terjadi infeksi opurtunistik yang mengancam kehidupan. ${ }^{22}$

7. Peran $\mathrm{Zn}$ pada fungsi indera pengecapan. Defisiensi $\mathrm{Zn}$ juga berhubungan dengan hipogeusia atau kehilangan indera pengecapan/rasa. Hipogeusia biasanya disertai penurunan nafsu makan (anoreksia) dan hiposmia (kehilangan indera penciuman). ${ }^{1}$ Umeta $\mathrm{dkk}^{23}$ di Ethiopia melakukan studi terhadap anak dengan perawakan pendek dengan memberikan suplementasi $\mathrm{Zn}$. Studi tersebut memperlihatkan penurunan bermakna keluhan anoreksia setelah mendapat suplementasi $\mathrm{Zn}$. Namun angka morbiditas yang tinggi juga mempengaruhi terjadinya defisiensi $\mathrm{Zn}$, sehingga sulit untuk menentukan apakah anoreksia yang terjadi hanya disebabkan oleh defisiensi $\mathrm{Zn}$ atau berhubungan dengan morbiditas. Pengaruh status Zn terhadap pertumbuhan dan nafsu makan berhubungan erat, sehingga dampak terhadap pertumbuhan dan nafsu makan dapat diperbaiki secara bersamaan dengan meningkatkan asupan Zn dalam makanan.

8. Sebagai antioksidan. Infeksi pada anak menyebabkan angka morbiditas meningkat. Infeksi akan menghasilkan radikal bebas yang merupakan molekul reaksi cepat, yang dapat menyebabkan kerusakan jaringan tubuh. Sebagai antioksidan yang berguna untuk menghancurkan radikal bebas, Zn merupakan unsur intrinsik yang sangat penting dari enzim superoksid dismutase (penghancur utama radikal bebas), yang terdapat pada berbagai jenis sel dan di ekstraselular. Superoksid dismutase akan mengubah super oksigen radikal bebas $\left(\mathrm{O}_{2}^{-}\right)$ menjadi hidrogen peroksida, yang kemudian akan diubah oleh katalase menjadi air dan oksigen. ${ }^{24}$ Sangat penting adanya keseimbangan antara produksi dan pengurangan radikal bebas dalam tubuh. Pada anak dengan gizi kurang yang mengalami kekurangan mikronutrien termasuk $\mathrm{Zn}$, akan terjadi gangguan keseimbangan ini. ${ }^{6}$

9. Faktor esensial dalam stabilisasi struktur membran sel, fungsi testikular dan spermatogenesis. ${ }^{15}$

\section{Zinkum dan pertumbuhan}

Zinkum berperan dalam reaksi yang luas dalam metabolisme tubuh, kekurangan $\mathrm{Zn}$ akan berpengaruh banyak terhadap jaringan tubuh tertentu pada saat 
pertumbuhan. ${ }^{1}$ Defisiensi Zn sering terjadi pada bayi dan anak, karena sedang terjadi pertumbuhan yang cepat. Penyebab defisiensi $\mathrm{Zn}$ pada bayi dan anak adalah asupan dan ketersediaan yang tidak adekuat, malabsorbsi, meningkatnya kehilangan $\mathrm{Zn}$ dari dalam tubuh, seperti pada diare yang merupakan penyebab terpenting kehilangan $\mathrm{Zn}$ melalui saluran cerna. ${ }^{12}$

Tanda-tanda dari defisiensi $\mathrm{Zn}$ pada anak adalah retardasi pertumbuhan, kematangan seksual terlambat, kelainan kulit dan rambut menjadi tipis, abnormalitas pada tulang dan sistem imunitas, serta mudah mengalami diare. ${ }^{2,12}$ Defisiensi $\mathrm{Zn}$ selalu dihubungkan dengan berkurangnya pertumbuhan pada bayi dan anak di negara berkembang. ${ }^{25}$ Retardasi pertumbuhan mempunyai prevalensi yang tinggi pada anak. Lebih kurang $43 \%$ anak usia di bawah 5 tahun di dunia $( \pm 230$ juta anak) adalah pendek. ${ }^{26}$

Banyak penelitian mengenai pengaruh suplementasi $\mathrm{Zn}$ terhadap pertumbuhan bayi dan anak di negara berkembang mendapatkan hasil yang berbeda. Beberapa penelitian mendapatkan hasil, bahwa suplementasi Zn selama 6 bulan memberikan dampak yang bermakna terhadap tinggi badan dan berat badan. Sedangkan penelitian lain dengan pemberian $\mathrm{Zn}$ selama 6 sampai 12 bulan, tidak memberikan dampak terhadap pertumbuhan. ${ }^{27}$ Ruel $\mathrm{dkk}^{28}$ melakukan penelitian pada bayi di Guetemala, mendapatkan hasil bahwa pada bayi yang mendapat suplementasi $\mathrm{Zn}$ terjadi pengurangan insiden diare dan suplementasi Zn efektif terhadap pertumbuhan bayi yang ditandai dengan peningkatan berat badan dan panjang badan. Roy dkk ${ }^{29}$ di Bangladesh, mendapatkan hasil bahwa suplementasi Zn merupakan strategi yang sederhana, mudah diterima, dan bermanfaat yang harus dipertimbangkan dalam tata laksana diare akut serta untuk mencegah retardasi pertumbuhan pada anak terutama yang mengalami malnutrisi. Penelitian oleh Sur dkk (1999-2001) ${ }^{30}$ di India memperlihatkan hasil bahwa suplementasi $Z n$ efektif dalam mengurangi insiden diare dan peningkatan berat badan dan pertumbuhan linear bayi dengan berat badan lahir rendah. Studi meta-analisis oleh Brown ${ }^{31}$ menyatakan bahwa suplementasi $\mathrm{Zn}$ memberikan respon positif yang sangat bermakna terhadap penambahan berat badan anak. Duran dan Weisstaub ${ }^{32}$ di Chile melakukan studi analisis dampak suplementasi $\mathrm{Zn}$ pada bayi dengan berat badan lahir rendah. Mereka mendapatkan hasil suplementasi $\mathrm{Zn}$ memberikan dampak positif terhadap pertumbuhan.

\section{Kelebihan zinkum}

Kelebihan Zn hingga 2-3 kali angka kecukupan gizi (AKG) menurunkan penyerapan tembaga. Percobaan pada hewan, hal ini menyebabkan degenerasi otot jantung. Kelebihan sampai sepuluh kali AKG mempengaruhi metabolisme kolesterol, mengubah nilai lipoprotein dan mungkin dapat mempercepat timbulnya aterosklerosis. Dosis $\geq 2$ gram dapat menyebabkan muntah, diare, demam, kelelahan yang sangat, anemia, dan gangguan reproduksi. Suplemen Zn dapat menyebabkan keracunan, begitu juga dengan makanan yang disimpan didalam kaleng yang dilapisi seng. ${ }^{1}$

Sebagai kesimpulan, dilaporkan bahwa zinkum merupakan mineral mikro (trace element) yang sangat penting setelah besi, berperan dalam banyak enzim untuk metabolisme tubuh, produksi hormon pertumbuhan, sebagai antioksidan dan diperlukan dalam fungsi imunitas yang dapat mencegah infeksi seperti infeksi saluran nafas, malaria dan diare. Dalam proses pertumbuhan, $\mathrm{Zn}$ berperan dalam sintesis protein yang dibutuhkan untuk pembentukan jaringan baru, pertumbuhan, dan perkembangan tulang yang normal. Pemberian suplementasi $\mathrm{Zn}$ pada bayi dan anak memberikan efek yang positif terhadap pertumbuhan.

\section{Daftar Pustaka}

1. Almatsier S. Prinsip dasar ilmu gizi. Jakarta: PT Gramedia Pustaka Utama; 2003.h.257-61

2. Smolin LA, Grosvenor MB. Nutrition: science and applications. Florida: Saunder College Publishing; 1994. h.350-65.

3. Groff JL, Gropper SS, Hunt SM. Advanced nutrition and human metabolisme. New york: West Publishing Company; 1995.h.366-75.

4. Soetjiningsih. Tumbuh kembang anak. Jakarta: EGC Penerbit Buku Kedokteran;1995. h.1.

5. Pudjiadi S. Ilmu gizi klinis pada anak. Edisi ke-4. Jakarta: FKUI;2000.h.205-6.

6. King FS, Burgess A. Nutrition for developing countries. Edisi ke-2. Oxford: Oxford University Press; 1996.h.42-3.

7. Black RE. Therapeutic and preventive effects of zinc on serious childhood infectious diseases in developing countries. Am J Clin Nutr 1998;68:476-9. 
8. Thu BD, Schultink W, Dillon D, Gross R, Leswara ND, Khio $\mathrm{HH}$. Effect of daily and weekly micronutrient supplementation on micronutrient deficiencies and growth in young Vietnamese children. Am J Clin Nutr 1999;69:80-6.

9. Rahman MM, Tofail F, Wahed MA, FuchsGJ, Baqui $\mathrm{AH}$, Alvarez JO. Short-term supplementation with zinc and vitamin A has no significant effect on the growth of undernourished Bangladeshi children. Am J Clin Nutr 2002;75:87-91.

10. Hadi H. Beban ganda masalah gizi dan implikasinya terhadap kebijakan pembangunan kesehatan nasional. Disampaikan pada Pidato Pengukuhan Jabatan Guru Besar Pada Fakultas Kedokteran Universitas Gadjah Mada; 5 Februari 2005. Yogyakarta : Fakultas Kedokteran Universitas Gadjah Mada, 2005.

11. Atmarita. Nutrition Problems in Indonesia. Disampaikan pada Seminar "An integrated international seminar and workshop on lifestyle - related disease"; 19-20 March, 2005. Yogyakarta : Universitas Gajah Mada, 2005.

12. Morrow FD. Clinical assesment of the nutritional status of adult. Dalam: Linder MC, penyunting. Nutritional biochemistry and metabolism with clinical applications. Edisi ke-2. California: Prentice - Hall International Inc; 1991.h.226-30.

13. Lutz CA, Przytulski KR. Nutrition and diet therapy. Philadelphia: F.A. Davis Company;1994. h.192-5.

14. Walker WA, Watkins JB. Nutrition in pediatrics. Basic science and clinical application. Edisi ketiga. Boston: Little, Brown and Company; 2003. h.18-29.

15. Robinson CH, Lawler MR, Chenoweth WL, Garwick AE. Normal and therapeutic nutition. Edisi ke-17. New York: Macmillan Publishing Company;1986. h.129-30.

16. Hambidge M. Trace element deficiencies in chidhood. Dalam: Suskind RM, Suskind LL, penyunting. Textbook of pediatric nutrition. Edisi ke-2. New York: Raven Press; 1993.h.115-21.

17. Diaz-Gomez NM, Domenech E, Barroso F, Castells S, Cortabarria C, Jimenez A. The effect of zinc supplementation on linear growth, body composition, and growth factor in preterm infants. Pediatrics 2003;111:1002-9.

18. Dijkhuizen MA, Wieringa FT, West CE, Muherdiyantiningsih, Muhilal. Concurrent micronutrient deficiencies in lactating mothers and their infants in Indonesia. Am J Clin Nutr 2001;73:786-91.

19. Krebs NF, Hambidge KM, Primak LE. Normal childhood nutrition \& its disorder. Dalam: Hay WW, penyunting. Current pediatrics diagnosis \& treatment.
Edisi ke-16. New York: Lange Medical Books/Mc GrawHill; 1999.h.285.

20. Shankar AH, Prasad AS. Zinc and immune function: the biological basis of altered resistance to infection. Am J Clin Nutr 1998;68:447-63.

21. Fraker PJ, King LE, Laakko T, Vollmer TL. The dinamic link between the integrity of the immune system and zinc status. J Nutr 2000;130:1399-406.

22. Bogden JD, Louria DB. Micronutrients and imunity in older people. Dalam: Bendich A, Deckelbaum RJ, penyunting. Preventive nutrition. The comprehensive guide for health professionals. New Jersey: Humana Press; 1997.h.317-25.

23. Umeta M, West CE, Haidar J, Deurenberg P, Hautvast JG. Zinc supplementation and stunted infants in Ethiopia: a randomised controlled trial. The Lancet 2000;355:2021-6.

24. Wapnir RA. Zinc defisiensi, malnutrition and the gastrointestinal tract. J Nutr 2000;130:1388-92.

25. Osendarp SJM, Santosham M, Black RE, Wahed MA, Van Raaij JMA, Fuchs GJ. Effect of zinc supplementation between 1 an 6 mo of life on growth and morbidity on Bangladeshi infants in urban slums. Am J Clin Nutr 2002;76:1401-8.

26. Rivera JA, Ruel MT, Santizo MC, Lonnerdal B, Brown $\mathrm{KH}$. Zinc supplementation improves the growth of stunted rural Guatemalan infants. J Nutr 1998;128:55662.

27. World Health Organization. Complementary feeding of young children in-developing countries: a review of current scientific knowledge. Geneva: WHO; 1998.h.7981.

28. Ruel MT, Rivera JA, Santizo MC, Lonerdal B, Brown $\mathrm{KH}$. Impact of zinc supplementation on morbidity from diarrhea and respiratory infections among rural Guatemalan children. Pediatrics 1997;99:808-13.

29. Roy SK, Tomkins AM, Akramuzzaman SM, Behrens RH, Haider R, Mahalanabis D dkk. Randomized controlled trial of zinc supplementation in-malnourished Bangladeshi children with acute diarrhoea. Arch Dis Child 1997;77:196-200.

30. Sur D, Gupta DN, Mondal SK, Ghost S, Manna B, Rajendran K dkk. Impact of-zinc supplementation on diarrheal morbidity and growth pattern of low birthweight infants in Kolkata, India: a randomized, doubleblind, pacebo-controlled, community-based study. Pediatrics 2003;112:1327-32.

31. Brown KH, Peerson JM, Rivera J, Allen LH. Effect of supplemental zinc on the-growth and serum zinc 
Leon Agustian dkk: Zinkum terhadap pertumbuhan anak

concentrations of prepubertal children: a meta - analysis of randomized controlled trials. Am J Clin Nutr 2002;75:1062-71.
32. Duran CC dan Weisstaub G. Zinc Supllementation and growth of the fetus and low birth weigh infant. J Nutr 2003;133:1494-7. 